\title{
Stochastic block models for community detection in heterogeneous networks
}

\author{
Hamed Kabiri Kenari ${ }^{1}$ \\ ${ }^{1}$ Kharazmi University
}

November 30, 2021

\section{Hosted file}

paper.pdf available at https://authorea.com/users/448523/articles/547321-stochastic-blockmodels-for-community-detection-in-heterogeneous-networks 